POŠTA

TELEKOMUNIKACIE A

ELEKTRONICKY OBCHOD

\title{
PLATOBNÉ SYSTÉMY A BEZHOTOVOSTNÝ PLATOBNÝ STYK VO VYBRANÝCH KRAJINÁCH EÚ
}

\author{
Martina Kováčiková ${ }^{1}$ Michaela L'ubeková $^{2}$
}

\begin{abstract}
The payment system can be perceived as a certain system forming an important part of the financial infrastructure of a market economy. Payments are made in non-cash and cash form. In the case of non-cash form, the presence of a payment system is required, by means of which transfers of funds are ensured. The interbank payment system is a system where direct participants are represented by banks and is generally based on a correspondence or clearing settlement system. The article describes the types of payment systems within the euro area and the Visegrad Group countries and their basic characteristics.
\end{abstract}

Keywords: euro area, payment system.

Úvod

Platobný styk je možné vnímat' ako určitý systém tvoriaci dôležitú súčast' finančnej infraštruktúry trhovej ekonomiky. Ide o systém, v rámci ktorého prebiehajú hotovostné platby vo forme obeživa prostredníctvom nebankových subjektov a bezhotovostné platby formou bankovej platby prostredníctvom vkladov na bankových účtoch. Pri hotovostnom platobnom styku sa väčšinou proces platby realizuje bez účasti banky. Pri bezhotovostnom platobnom styku dochádza $\mathrm{k}$ úhrade/inkasu bezhotovostným prevodom $\mathrm{z}$ účtu banky príkazcu na účet banky prijímatel'a. Podmienkou pre bezchybné prevádzkovanie bezhotovostného platobného styku je nutná existencia platobného systému pre zúčtovanie platieb.

\section{Charakteristika platobného systému}

Platobný systém (payment system), alebo systém prevodu prostriedkov (funds transfer system) je systém, ktorý zaist'uje bezhotovostné prevody finančných prostriedkov. Platobný systém môže byt' realizovaný:

- na princípe zúčtovania jednotlivých položiek pri súčasnej kontrole ich krytia (hrubý platobný systém),

- na princípe zúčtovania rozdielov (sald) vypočítaných zo vzájomných pohl'adávok a záväzkov účastníkov systému (čistý platobný systém),

- na základe kombinácie oboch princípov uvedených vyššie.

Z právneho hl'adiska sa jedná o dohodu založenú na súkromnom kontrakte, alebo na základe zákona. [1] Dohoda sa vyznačuje viacnásobným členstvom, zahŕňa súhrn pravidiel, inštitúcií a technických mechanizmov, ktoré majú za úlohu efektívne, spol'ahlivo, rýchlo a hlavne včas prevádzat' finančné prostriedky vo forme peňazí z účtu príkazcu na účet príjemcu.

V súvislosti s platobnými nástrojmi je možné špecifikovat' dve skupiny platobných nástrojov: tradičné platobné nástroje (zmenky, šeky, príkazy na úhradu/inkaso, dokumentárne

\footnotetext{
${ }^{1}$ Ing. Martina Kováčiková, PhD., Katedra spojov, FPEDAS, Žilinská univerzita v Žiline, e-mail: martina.kovacikova@fpedas.uniza.sk

${ }^{2}$ Ing. Michaela L’ubeková, Katedra spojov, FPEDAS, Žilinská univerzita v Žiline
} 
akreditívy a iné) a alternatívne platobné nástroje (platobné karty, elektronické prevody finančných prostriedkov, internetové bankovníctvo, e-commerce platobné systémy a iné).

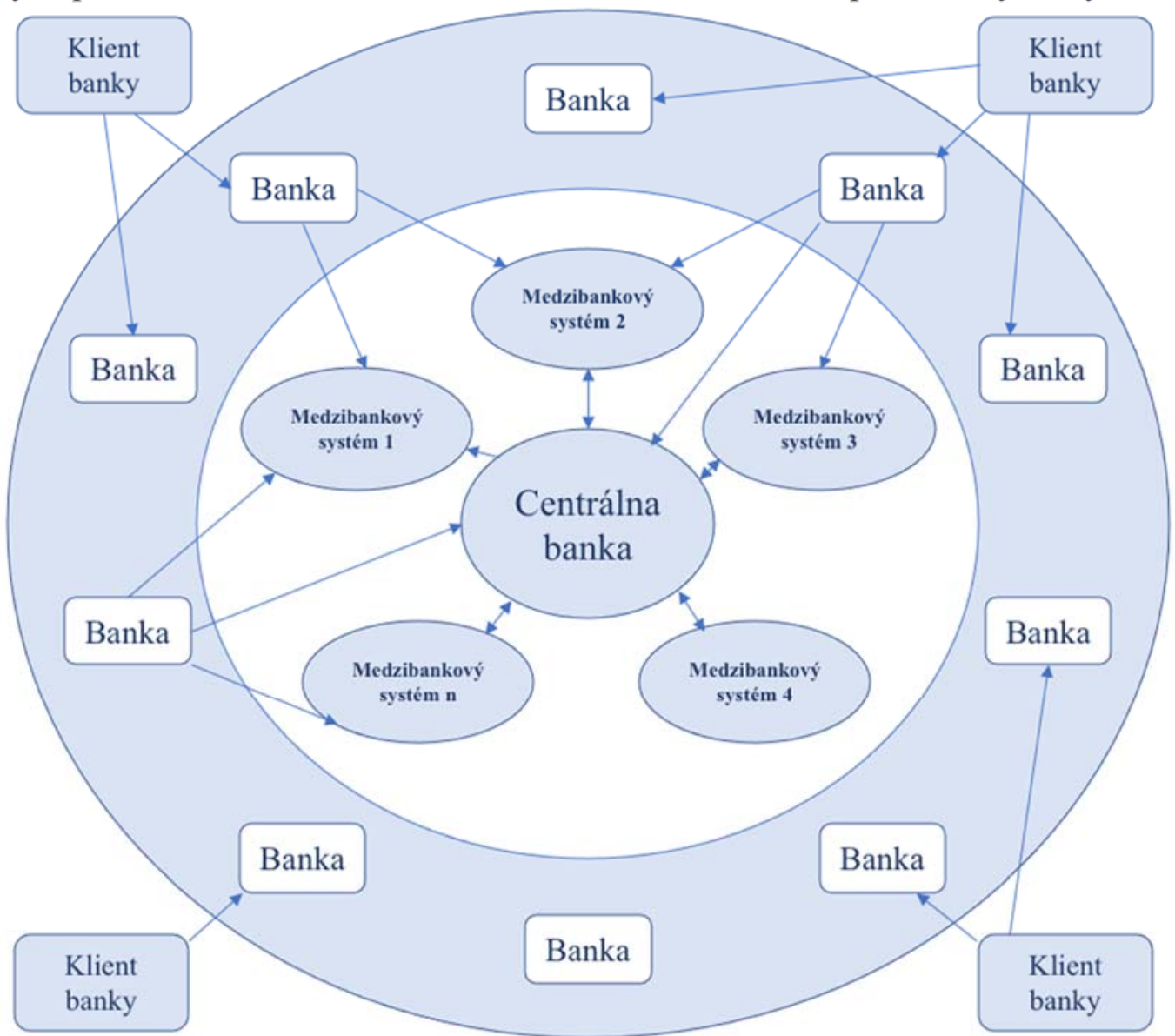

Obrázok 1 Platobné systémy v krajine alebo v menovej oblasti, vlastné spracovanie podl’a [13]

Model platobného systému (Obrázok č. 1) je možné chápat' ako siet' zloženú z bánk a iných ekonomických subjektov. Platobná transakcia a prevod finančných prostriedkov sa uskutočňuje prostredníctvom bánk a iných sprostredkovatel'ov, ktorí sú spojení prostredníctvom medzibankových alebo centrálnych bankových systémov. Zákazník jednej, alebo viacerých bánk - môže otvorit' l'ubovol'ný počet depozitných účtov. Banky sú účastníkmi mnohých medzibankových systémov a systému centrálnych bánk na zúčtovanie a vyrovnanie svojich platobných transakcií. Transakcií sa môžu zúčastňovat' ako priami alebo nepriami účastníci a samozrejme zohrávajú úlohu sprostredkovatel'ov medzi medzibankovými systémami a koncovými stranami. Systém centrálnej banky je umiestnený v strede modelu. To zdôrazňuje dôležitú úlohu, ktorú centrálna banka zohráva ako orgán dohl'adu nad bankovými a menovými systémami v krajine alebo menovej zóne. Konečné vyrovnanie pohladávok $\mathrm{z}$ medzibankových operácií sa vykonáva v systéme centrálnych bánk, ktorý sa považuje za hlavný platobný systém, zatial' čo medzibankové systémy sa považujú za pridružené systémy. [2,13]

\section{Priebeh platieb v platobných systémoch}

Priebeh platby v platobnom systéme môže byt' realizovaný korešpondenčným, alebo clearingovým platobným systémom.

V korešpondenčnom platobnom systéme vystupujú banky, ktoré sú spojené cez vzájomne otvorené účty platobného styku (tzv. nostro a loro účty). Pre realizáciu prevodu platby je nevyhnutné, aby mali zúčastnené banky medzi sebou priame bankové spojenie. Ak je pre zahraničnú banku ponuka potrebná a vyhovujúca, dôjde $\mathrm{k}$ dohode o konkrétnych podmienkach. 
V prípade, že banky realizujúce priebeh platby nemajú priame spojenie, vstupuje do priebehu platby tretia strana - korešpondenčná banka bánk, medzi ktorými prebieha platba. [3]

Zúčtovanie v clearingovom platobnom systéme prebieha prostredníctvom zúčtovacej banky (centrálnej banky), v ktorej majú ekonomické subjekty otvorený nostro účet, cez ktorý prebiehajú všetky platby s ostatnými napojenými bankami. Výhodou clearingového systému je, že banky nemusia mat' $v$ ostatných bankách otvorené účty a tým odpadá nutnost' mat' viaceré účty v mnohých bankách a banka v platobnom styku má viazaných i menej prostriedkov. [4] $\mathrm{Na}$ priebehu platby prostredníctvom platobných systémov participujú okrem platobného systému aj jeho používatelia - účastníci, ktorí môžu byt' kategorizovaní ako priami, nepriami, alebo vzdialení v závislosti od prístupu k národnému RTGS (Real-time gross settlement systém prevodu prostriedkov), $\mathrm{v}$ ktorom sa peniaze prenášajú $\mathrm{z}$ jednej banky do druhej $\mathrm{v}$ „reálnom čase“, v hrubom vyjadrení. Účastníci platieb:

- priamym účastníkom je subjekt, ktorý má priamy prístup k národnému systému RTGS a vlastní účet RTGS v príslušnej národnej centrálnej banke. Priamym účastníkom národného systému RTGS sa môže stat'iba dohliadaná úverová inštitúcia, ktorá má sídlo v krajine patriacej do EHP (Európskeho hospodárskeho priestoru), resp. výnimočne (so súhlasom príslušnej národnej centrálnej banky) aj d’alšie vymedzené subjekty (podl'a Usmernenia Európskej centrálnej banky o TARGET - Trans-European Automated Real-time Gross settlement Express Transfer system),

- nepriamym účastníkom je inštitúcia, ktorá nemá vlastný RTGS účet, napriek tomu je však národným RTGS systémom uznaná, podlieha jeho pravidlám a je ju možné v TARGET-e priamo kontaktovat'. Všetky transakcie nepriameho účastníka sa vykonávajú na účte priameho účastníka, ktorý súhlasil s jeho zastupovaním,

- podstatou „Vzdialeného prístupu“ (tzv. remote access) je to, že inštitúcia sídliaca v členskej krajine EHP môže získat' priamy prístup do národného platobného systému RTGS (napojeného na TARGET) iného členského štátu EÚ (Európskej únie) - tzv. hostitel'ský štát. Na tento účel má v národnej centrálnej banke hostitel'ského členského štátu otvorený účet RTGS v eurách na svoje vlastné meno bez toho, aby musela mat'v hostitel'skom štáte zriadenú svoju pobočku (resp. dcérsku spoločnost'). [5]

Účastníkmi platobných systémov môžu byt': centrálne banky, centrálne klíringové inštitúcie, komerčné banky, nebankové inštitúcie.

Z hl'adiska objemu platieb je možné rozlíšit' dva typy platobných systémov:

- maloobjemové platobné systémy sú systémy, ktoré slúžia pre každodenné bežné transakcie,

- vel'koobjemové platobné systémy slúžia aby medzibankové trhy správne fungovali. Sú realizované promptne a poskytujú sa len vybranému okruhu účastníkov ako sú napríklad centrálne banky, finančné inštitúcie a iné.

V jednotlivých krajinách môžu existovat' rozdielne prístupy $\mathrm{v}$ oblasti platobných systémov. V rámci EÚ zohráva napr. úlohu, či je krajina súčast'ou eurozóny alebo nie, či používa jednotnú menu euro alebo svoju domácu menu a iné. Práve v súvislosti s touto rôznorodost'ou špecialisti a inštitúcie, zodpovedajúci za prevádzku a kontrolu platobných systémov, zadefinovali základné princípy, pre správnu funkciu platobných systémov, ktoré zahŕňajú: cenovú stabilitu, národný menový režim, technickú výkonnost' a efektívnost' platobného systému, efektívne riadenie operácií, oficiálny dohl'ad a dozor, medzibankové úhrady a úlohy centrálnej banky a v neposlednom rade kvalitný legislatívny rámec. Základné princípy platobných systémov sú vyjadrené všeobecne, aby mohla byt' zabezpečená, ich užitočnost' vo všetkých krajinách, a tiež ich trvalost'. Nepredstavujú plán pre návrh platobného 
systému, alebo ako by mal správne fungovat' ktorýkol'vek platobný systém, ale naznačujú kl'účové charakteristiky, ktoré by mali splňat' všetky systémovo dôležité platobné systémy. [6]

\section{Platobné systémy $v$ rámci eurozóny}

Zavedenie eura a jeho využívanie umožnilo vytvorit' nové platobné systémy, alebo zrenovovat' už existujúce platobné systémy. Tuzemský a zahraničný platobný styk musia banky a iné ekonomické inštitúcie, napríklad poist’ovne, penzijné fondy a iné, uskutočňovat' $\mathrm{v}$ jednotnej mene euro, $v$ reálnom čase a v rámci celej EÚ. Pre zrealizovanie takéhoto styku v EÚ funguje viacero clearingových platobných systémov, schopných uskutočnit' transakcie v krátkom časovom slede a dokážu spracovat' vel'ký počet platobných príkazov.

V rámci eurozóny sú zriadené tieto platobné systémy:

- TARGET - Trans-European Automated Real-time Gross settlement Express Transfer system - transeurópsky automatizovaný expresný prevod hrubého zúčtovania platieb v reálnom čase,

- STEP1 - Straight Through Euro Payment processing system - spracovanie jednotlivých komerčných platieb, je komplementárny k systému EURO1

- EURO1 - systém na paneurópskej úrovni poskytujúci vysporiadanie platieb vel'kej hodnoty $\mathrm{v}$ rámci jedného dňa $\mathrm{v}$ eurách $\mathrm{v}$ súkromnom sektore,

- STEP2 - platobný systém, prevádzkovaný spoločnost'ou EBA CLEARING, prostredníctvom ktorého Národná banka Slovenska zabezpečuje spracovanie cezhraničných úhrad (SEPA),

- TARGET2 - the second-generation Trans-European Automated Real-time Gross settlement Express Transfer system - druhá generácia transeurópskeho automatizovaného expresného prevodu hrubého zúčtovania platieb v reálnom čase,

- SEPA - Single Euro Payments Area - jednotná oblast' platieb v eurách.

Pred zavedením eura sa cezhraničné platby spracovávali prostredníctvom systému korešpondenčného bankovníctva. Prvé cezhraničné platby $\mathrm{v}$ eurách boli sprostredkované $\mathrm{v}$ systémoch EURO1 a TARGET. Systém TARGET bol spustený v rovnakom čase ako menová únia v januári 1999. TARGET je jedným z najväčších platobných systémov na svete. EURO1 je jediný platobný systém s vysokou hodnotou v súkromnom sektore pre jednodňové transakcie v eurách. Tento systém dopĺńa platobný systém STEP1, ktorý poskytuje spracovanie pre maloobchodné platby. Patrí do maloobjemového platobného systému ako platobný systém STEP2, ktorý spracováva prevodové príkazy SEPA a úverové prevody SEPA. Dalším systémom je TARGET2, ktorý je novou generáciou systému TARGET. Všetky štyri systémy sú systémom hrubého vyrovnania $v$ reálnom čase.

Pre ilustráciu počtu a objemu spracovaných platieb, prostredníctvom uvedených systémov, môže slúžit' nižšie uvedená Tabul'ka 1, v ktorej sú porovnané počty a hodnoty transakcií uskutočnených v platobných systémoch za rok 2019.

Tabul'ka 1 Platobné systémy v rámci eurozóny

\begin{tabular}{|l|c|c|}
\hline $\begin{array}{c}\text { Platobné systémy v rámci } \\
\text { eurozóny }\end{array}$ & Počet spracovaných platieb & $\begin{array}{c}\text { Hodnota spracovaných } \\
\text { platieb (mld. } € \text { ) }\end{array}$ \\
\hline TARGET2 & 342315684 & 1100733 \\
\hline EURO1/EURO2 & 52744488 & 529778 \\
\hline STEP2 & 6723738445 & 20535 \\
\hline
\end{tabular}

Zdroj: vlastné spracovanie podl'a $[7,8]$ 


\section{Platobné systémy na Slovensku a v krajinách V4}

Slovensku sú od 1.1.2009, teda od zavedenia meny euro, realizované bankové platby prostredníctvom dvoch platobných systémov, ktoré predstavujú: slovenský EURO SIPS (SIPS - platobný systém, prevádzkovaný Národnou bankou Slovenska) a napojenie na platobný systém TARGET2 prostredníctvom slovenského komponentu TARGET2-SK (slovenský platobný systém TARGET2).

Po prijatí eura nahradil teda medzibankový platobný systém SIPS nový platobný systém EURO SIPS. Jeho spustenie začalo 31. 12. 2008. Funguje podobne ako jeho predchodca SIPS. EURO SIPS je retailovým platobným systémom, ktorý má za úlohu spracovanie clearingových klientskych platieb v eurách a zároveň je pridruženým platobným systémom k TARGET2-SK. Prostredníctvom systému sa zabezpečuje spracovanie SEPA platieb na území Slovenska a krajín EHP. Výmena dát medzi týmito platobnými systémami sa realizuje cez SWIFT-Net siet' (The Society for Worldwide Interbank Financial Telecommunication - spoločnost' pre celosvetovú medzibankovú finančnú telekomunikáciu). Platobné transakcie sa spracovávajú v clearingových cykloch a následne sa výsledky finančne vyrovnávajú v systéme TARGET2-SK. Clearingový cyklus zahŕňa časové pásmo, ktoré obsahuje otvorenie, zúčtovanie príkazov, ukončenie, odoslanie príkazov do TARGET2, potvrdenie o ich vyrovnaní v TARGET2 a následné odoslanie údajov transakcie účastníkom systému. [9] Priebeh platby v TARGET2-SK, je umožnený iba tomu priamemu účastníkovi, ktorý má založený RTGS účet. Samotné platby sú realizované na základe platobných správ formátu SWIFT. Ked’ je platba overená a autorizovaná, prebehne kontrola syntaxe SWIFT správy. Platby sú zúčtované okamžite, pokial' je na účte RTGS účastníka dostatočná likvidita. [8]

Vyšehradská skupina (V4) je zložená zo štyroch stredoeurópskych krajín - Slovenskej republiky, Českej republiky, Mad’arskej republiky a Pol'skej republiky. Štáty sú členmi EÚ a NATO. Státy sa hlásia k rovnakým hodnotám, ktoré majú spoločnú históriu a kultúru. Vzhl'adom na to, že nie všetky krajiny V4 patria do eurozóny, je odlišný aj spôsob spracovania a realizácie cezhraničných medzibankových platieb.

Platobný systém CERTIS (Czech Express Real Time Interbank Gross Settlement system), ktorý je prevádzkovaný v Českej republike je tu jediným systémom medzibankového platobného styku. CERTIS je založený na postupoch zúčtovania v reálnom čase. Zúčtovanie medzibankových platieb je v českých korunách bez ohl'adu na čiastku i bez ohl'adu na to, či tieto platby boli iniciované príkazom klienta banke priamo alebo nepriamo. Zúčtovanie $\mathrm{v}$ peniazoch centrálnej banky prebieha na účtoch medzibankového platobného styku vedených $\mathrm{v}$ ČNB, ktoré zároveň slúžia ako účty povinných minimálnych rezerv. Systém spracováva rôzne typy transakcií: úhrady, inkasá, storná úhrad, transakcie pridružených systémov a informačných a kontrolných položiek. [8]

Platobný systém VIBER (Real-time Gross Settlement System), v ktorom sa uskutočňujú a zúčtovávajú nie len bankové platby, ale aj obchodovanie s cennými papiermi mad’arského platobného systému KELER (zahŕňa kl'účové inštitúcie infraštruktúry peňažného a kapitálového trhu). Systém VIBER spracováva transakcie bez ohl'adu na ich hodnotu. Typy transakcií, ktoré je možné vyrovnat' v systéme VIBER medzi bankami sú objednávky iniciované klientmi, transakcie s cennými papiermi a transakcie centrálnej banky Mad'arska. Účastníci iní ako MNB (Mad'arská národná banka) a KELER môžu iniciovat' úhrady iba odoslaním platobnej správy SWIFT. [8]

SORBNET2 (new generation Real-Time Gross Settlement) je systém prevádzkovaný Pol'skou národnou bankou. Systém SORBNET2 sa používa aj na vyrovnanie záväzkov bánk vyplývajúcich zo zúčtovacích systémov KIR (systém pre retailové platby) a KDPW (systém pre transakcie na kapitálovom trhu). Systém SORBNET2 podporuje najmä bežné účty bánk v domácej mene, prostredníctvom ktorých sa uskutočňujú medzibankové zúčtovania za platby v domácej mene. Patrí do triedy systémov RTGS alebo zúčtovacích systémov v hrubom 
vyjadrení, v ktorých sa objednávky realizujú jednotlivo a v reálnom čase. Výmena platobných údajov medzi účastníkmi NBP (Národná banka Pol'ska) a účastníkmi systému sa realizuje prostredníctvom medzinárodnej telekomunikačnej siete SWIFT. [8]

Pre doplnenie informácií o priebehoch platieb v spomínaných krajinách, je vhodné uviest' ich domáce meny. Pol'ská, Česká a Mad’arská republika, nie sú členmi eurozóny, platby sú teda realizované v ich národnej mene. V Česku je to CZK (koruna česká), v Pol'sku PLN (pol'ský zlotý) a v Mad'arsku HUF (mad'arský forint). Na Slovensku, ktoré je členským štátom eurozóny, sú platby realizované v eurách (rovnako ako vo všetkých krajinách eurozóny).

V súvislosti s komparáciou vyššie uvedených platobných systémov vybraných krajín, je možné záverom uviest' zistenie, že hl'adiska princípu fungovania a zúčtovania platobných systémov, pracujú všetky štyri systémy na rovnakom princípe zúčtovania a to $\mathrm{v}$ reálnom čase. Rovnako prevádzkovanie systémov v krajinách V4 majú v kompetencii národné banky. Sledovaním typov platieb bolo zistené, že $\mathrm{v}$ súvislosti $\mathrm{s}$ ich realizáciou, zabezpečujú tieto systémy realizáciu rovnakých typov platieb ako sú úhrady, inkasá a transakcie pridružených platobných systémov. Všetky systémy dávajú svojím používatel'om možnost' zvolit' si niekol'ko stupňov priority a následne ich pripojit' $\mathrm{k}$ platbe. Z hl'adiska priebehu je oblast' spracovania transakcie, vzhl'adom na využívaný RTGS systém, znázornená na Obrázku č. 2., kde je vyzdvihnutý zistený rozdiel $\mathrm{v}$ priebehu realizácie bezhotovostných prevodov $\mathrm{v}$ rámci Slovenska a porovnávaných krajín.

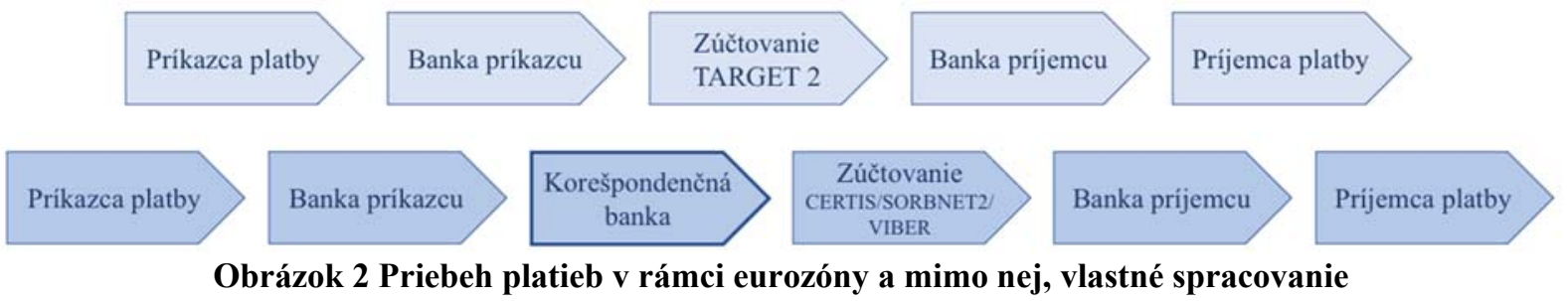

Po porovnaní platobných systémov, sa javí ako výhodnejšie zúčtovanie prostredníctvom platobného systému TARGET2-SK. Nielen že je pridruženým systémom TARGET2, ktorý patrí medzi najväčšie platobné systémy na svete, ale v rámci priebehu transakcie nie je vyžadovaná prítomnost' korešpondenčnej banky. TARGET2 zároveň prezentuje myšlienku zjednotenia krajín, čo sa týka meny a platieb medzi krajinami, s rovnakými pravidlami, zásadami a jednotnou menou.

V rámci uvedenej problematiky je vhodné spomenút', rovinu polemiky vzhl'adom na možnú „diskrimináciou“ používatel’ov platobných služieb v krajinách EÚ, ktorých menou nie je euro. Práve v tejto súvislosti vstúpilo do platnosti nariadenie Európskeho parlamentu a Rady (EÚ) 2019/518 z marca 2019, ktorým sa upravujú niektoré poplatky za cezhraničné platby v EÚ a poplatky za menovú konverziu. [12]

\section{Záver}

Ciel'om príspevku bolo priblížit' oblast' platobných systémov využívaných v rámci bezhotovostného prevodu finančných prostriedkov. V rámci užšej špecifikácie je zameranie smerované na platobné systémy prevádzkované v Európskej únii. $\mathrm{V}$ tejto súvislosti je tiež vhodné zhrnút' základné míl'niky v sledovanej oblasti dotýkajúce sa aj Slovenskej republiky: v Európskej únií bol ako prvým systémom, cez ktorý boli sprostredkované cezhraničné platby v eurách EURO1 a TARGET. TARGET si dodnes drží prvenstvo medzi najväčšími platobnými systémami na svete. Ďalší systém, ktorý vznikol a dopĺn̆a systém EURO1 je STEP1. Neskôr bol zavedení aj STEP2, ktorý má na starosti prevodové príkazy SEPA. A ako posledný v Európskej únií vznikol TARGET2, ktorý je nástupcom TARGET. Na Slovensku po zavedení eura spustili platobný systém EURO SIPS a TARGET2-SK. Vzhl'adom na zúčtovanie cezhraničných platieb je účtovanie $\mathrm{v}$ platobnom systéme TARGET2-SK bez účasti 
korešpondenčnej banky a zároveň reprezentuje systém platieb medzi krajinami, s rovnakými pravidlami, zásadami a jednotnou menou.

\section{Literatúra:}

[1] JÍLEK, J.: Peníze a měnová politika, 1. vyd., GRADA Publishing, a. s., Praha 2004, - 742 s., ISBN 80-247-0769-1

[2] Platobné systémy teraz. [online.] Dostupné na internete: <https:// www.digitalpaymentguru.com/payment-system-then-now/>.

[3] POLOUČEK, S. a kol.: Bankovnictví. 1. vyd. Praha : C.H. Beck, 2006. -716 s.ISBN: 97880-717-9462-2

[4] KUBRANOVÁ, M., SOCHOR, M.: Platobný styk a platobná schopnost' podniku. 1. vyd. Bratislava:EKONÓM, 2009. - 149 s. ISBN 978-80-225-2681-4

[5] Komparácia platobných systémov [online.] Dostupné na internete: $<$ http://www.profini.sk/komparacia-platobnych-systemov-target-a-target-2-druha-cast/>.

[6] Core Principles for Systemically Important Payment Systems [online]. Dostupné na internete: $<$ https://www.bis.org/cpmi/publ/d43.htm $>$.

[7] Výročná správa 2019 [online.] Dostupné na internete: $<$ https:// www.ecb.eu>

[8] LUBEKOVÁ, M.: Komparácia platobných systémov, Bakalárska práca, EDIS Žilinská univerzita v Žiline 2020, vedúci práce: Kováčiková M.

[9] Čo je to eurozóna? [online]. Dostupné na internete: $<$ https://ec.europa.eu/info/businesseconomy- euro/euro-area/what-euro-area $\mathrm{s}>$.

[10]MADLEŇÁK, R., MADLEŇÁKOVÁ, L.: Základy elektronického obchodovania / Radovan Madleňák, Lucia Madleňáková. - 1. vyd. - Žilina : Žilinská univerzita v Žiline, 2016. - 214 s., [AH 18,92]. - ISBN 978-80-554-1294-8

[11]REPKOVÁ ŠTOFKOVÁ, K., ŠTOFKOVÁ, J., KAŠTÁNEK, P., GAŠOVÁ, K.: Financie a finančné riadenie [print], Žilina, Žilinská univerzita, 2018. - 245 s. ISBN 978-80-554$1481-2$

[12]Úradný vestník Európskej únie. [online]. Dostupné na internete: < https://eurlex.europa.eu/legal-content/SK/TXT/PDF/?uri=CELEX:32019R0518\&from=SK >

[13] Payment, Payment Instruments and Payment Systems. [online]. Dostupné na internete: $<$ https://www.paiementor.com/payments-instruments-and-systems/>.

[14]ČOREJOVÁ, T., GARBÁROVÁ, M., MAJERČÁKOVÁ, M.: Vybrané kapitoly z medzinárodnej ekonomiky, 2. preprac. a dopl. vyd. - Žilina : Žilinská univerzita, 2016. 219 s., [AH 17,25; VH 17,79]. - ISBN 978-80-554-1195-8

[15]SEPA. [online.] Dostupné na internete: <http://www.fininfo.sk/sk/eu-a-financnytrh/sepa/platobne-nastroje>.

[16]CERTIS. [online]. Dostupné na internete: <https://www.cnb.cz/cs/ platebnistyk/certis/ popis-systemu-certis/>.

[17]STEP1. [online.] Dostupné na internete: <https:// www.ebaclearing.eu/ services/step1/overview/>.

[18] VIBER [online.] Dostupné na internete: $<$ https://www.mnb.hu/letoltes/viber-en.pdf $>$.

[19]SORBNET2 [online.] Dostupné na internete: <https://www.nbp.pl/home.aspx? $\mathrm{f}=/$ systemplatniczy/informacja_sorbnet $2 . h t m l>$.

\section{Grantová podpora}

VEGA 1/0755/18 Nové prístupy manažmentu k tvorbe stratégií podnikov pre podporu konkurencieschopnosti v podmienkach globalizácie 